\title{
The Influence of Islamic Corporate Governance on The Performance of Maqashid Sharia in Sharia Banking in Indonesia
}

\author{
Ria Safitri*1 and Hasan Mukhibad ${ }^{2}$ \\ 1,2 Accounting Department, Faculty of Economics, Universitas Negeri Semarang
}

\section{ARTICLE INFO}

\section{Article History:}

Received January $15^{\text {th }}, 2020$

Accepted March $3^{\text {th }}, 2020$

Available July $30^{\text {th }}, 2020$

\section{Keywords:}

maqashid sharia performance;

Sharia Supervisory Board

(SSB); ratio of independent

commissioners; and number

of board meeting

\begin{abstract}
This study aims to examine the effect of Islamic Corporate Governance (ICG) that consist of Sharia Supervisory Board (SSB) which is measured using education level, ratio of independent commissioners, and board of director meetings on maqashid sharia performance. The population in this study was Islamic Bank listed on the Financial Services Authority (FSA) in 2013-2018 as many as 11 Islamic Banks. The sampling technique used in this study was purposive sampling method and obtained as many as 54 units of analysis. Data collection used documentation technique. The analytical method used in this study was panel data regressions using Eviews 9. The results of the study indicate that Sharia Supervisory Board (SSB) which is measured using education level, ratio of independent commissioners, and board of director meeting of board do not have effect on maqashid sharia performance. The conclusion of this research is that maqashid sharia performance of Indonesian Islamic Bank just $34.138 \%$, that means maqashid sharia has not been a target priority in Indonesian Islamic Bank. Thus, the factors examined have not been optimized yet for achieving the goal of sharia (maqashid sharia).
\end{abstract}

(C) 2020 Published by UNNES. This is an open access article under the CC BY license (http://creativecommons.org/licenses/by/4.0/)

\section{INTRODUCTION}

Islam as a perfect religion has governed everything in human life, including financial problems. AlQur'an as a guide to the lives of Muslims has alluded to matters relating to finance, one of which is about human behavior in managing finances as a mandate and on the terms of financial transactions in accordance with Islamic law.

Sharia banking is banking based on sharia principles. The goal to be achieved in Islamic economics is to reach falah (world and hereafter victory). The same goal is also to be achieved by sharia banking, so that the goal is passed down to all parts of sharia banking, one of which is performance.

The performance of sharia banks needs to be assessed to provide an evaluation of the business viability that has been carried out and as a guide for improvement in the next period. The assessment of banking performance is carried out by all stakeholders in order to maintain stakeholder trust to the banking system. This assessment is important to be conducted as one of the

\footnotetext{
*E-mail: ryaasafitri2111@gmail.com

_Address: L2 Building 2nd floor, Campus Sekaran, Gunungpati, Semarang, Indonesia, 50229
}

references for stakeholder decision making.

According to Antonio, et al. (2012) measurement of company performance in the international world, including sharia banking is still limited to conventional ratio measurements such as CAMELS (Capital, Asset, Management, Earning, Liquidity, Sensitivity of Market Risk) and EVA (Economic Value Added). Measurements using conventional ratios only focus on achieving financial goals, but ignoring the achievement of sharia objectives.

Mohammed \& Razak (2008) explained that there is a need for a development in the measurement of sharia banking performance derived from sharia principles so that it is in accordance with sharia objectives (maqashid sharia). According to Rahman, et al. (2017) the purpose of maqashid sharia measurement is to evaluate the level of company performance in upholding Islamic values.

One of the basic differences in performance measurement between sharia and conventional banking is the difference in value and product produced by both (Rusydiana \& Sanrego, 2018). Measurement of sharia banking performance based on maqashid sharia which was first discovered by Mohammed \& Razak (2008) becomes important to be studied due to sharia banks are banks that have sharia principles, so this needs to be ap- 
plied in all aspects.

The achievement of maqashid sharia in sharia banking can be measured through the achievement of objectives in the form of individual education, the realization of justice and the achievement of public interests. Achievements of maqashid sharia in the past 5 years are shown in table 1 . During the last 5 years research, the average achievement of maqashid sharia index is in the range of $16.20 \%$ to $36.27 \%$. This achievement is still far from the ideal indicator of maqashid sharia achievement, which is $100 \%$, which can be seen in table 1 .

The achievement of maqashid sharia index which is still low shows that although maqashid sharia is a measurement that is considered to reflect the objectives of sharia that are different from conventional banking, in fact this is not the case. This result indicates that the performance of maqashid sharia has not been made as a priority in achieving sharia banking. Based on this information, it indicates thing that needs to be further investigated, namely about the factors that are able improve the performance of sharia banking using the maqashid sharia index.

Factors that influence the performance of maqashid sharia is Islamic Corporate Governance (ICG). Islamic Corporate Governance (ICG) is Good Corporate Governance (GCG) or corporate governance implemented in sharia agencies. Bhatti \& Bhatti (2010) defined Islamic Corporate Governance (ICG) as a way in which economic actors, the current system, and corporate governance are regulated based on Islamic law, so that the economic system, companies and business activities are based on Islamic paradigms, where the aim is to welfare individuals and society in general. In addition, according to Orazalin \& Mahmood (2019), banks with GCG practices can anticipate losses during financial crisis.

Based on research conducted by Windah \& Andono (2013), it is stated that GCG as a whole has not been able to represent a tool to achieve or maximize the welfare of all stakeholders, especially in developing countries such as Indonesia where the implementation of GCG is still very varied due to an inadequate legal environment. According to Prasinta (2012), the term of GCG is long term so that the success cannot be measured using performance measurement indicators that are short-term in nature.

This study examines the influence of ICG by reducing it to some variables, namely Sharia Supervisory Board (SSB) using SSB education level measure- ment, proportion of independent commissioners, and board of directors meetings. SSB by measuring the level of SSB education has only been examined for its influence on the performance of maqashid sharia by Mukhibad (2019) which shows no effect. The Effect of SSB variable being examined by Maria \& Agustina (2018) and Priatna (2018) affect the performance of maqashid sharia. Different results are shown through research conducted by Kholid \& Bachtiar (2015) and Mukhibad (2019) which show result that have no effect on the performance of maqashid sharia.

Research related to the effect of proportion of independent commissioners on performance still shows inconsistent results. Maria \& Agustina (2018) stated that the greater the proportion of independent commissioners, the greater the performance value of maqashid sharia. This is contrary to research by Hartono \& Nugrahanti (2014) and Mukhibad (2019) which find that the proportion of independent commissioners has no effect on company performance.

Research on the board of directors' meeting on the performance of maqashid sharia has only been examined once by Priatna (2018) which gives result that does not affect the performance of maqashid sharia. According to Hartono \& Nugrahanti (2014) and Adams \& Mehran (2012) showed that board of directors size has a significant positive effect on company performance. Research conducted by Al-Matari,et al. (2012) states that board size has a negative effect on company performance.

This study aims to determine the role of Sharia Supervisory Board, board of independent commissioners, and board of directors on the performance of maqashid sharia. The originality of this research is the use of Eviews 9 as a test tool. The reason for using Eviews 9 is because the data used is panel data so it is more appropriate to use Eviews as a test tool, in addition to the use of Eviews as far as researchers know it has never been used before in maqashid sharia research.

This study uses Sharia Enterprise Theory (SET) and stakeholder theory. According to Meutia (2010), Sharia Enterprise Theory (SET) is an axiom that is sourced from God, the Lord of all nature, so that views that God is the main source of trust. This makes everything that is done by Islamic banking actors must be in accordance with the goals set by God (maqashid sharia).

SET concept does not position humans as the center of everything as understood by anthropocentrism. But instead, SET puts God at the center of everything.

Table 1. MSI Score in the Last 5 Years Research

\begin{tabular}{ccccccc}
\hline Research (Name, Year) & Sample & $\begin{array}{c}\text { Total Sam- } \\
\text { ple }\end{array}$ & Research Year & $\begin{array}{c}\text { Highest } \\
\text { Score }\end{array}$ & Lowest Score & Mean \\
\hline Kholid \& Bachtiar (2014) & BUS & 9 & $2010-2013$ & $40.79 \%$ & $26.0 \%$ & $36.27 \%$ \\
Kholid \& Bachtiar (2015) & BUS & 7 & $2010-2014$ & $36.09 \%$ & $26.0 \%$ & $31.62 \%$ \\
Sudrajat \& Sodiq(2016) & BUS & 9 & $2011-2015$ & $37.60 \%$ & $18.76 \%$ & $28.65 \%$ \\
Holili (2017) & BUS & 11 & $2013-2015$ & $63.41 \%$ & $-96.51 \%$ & $16.20 \%$ \\
Priatna (2018) & BUS & 6 & $2012-2016$ & $35.53 \%$ & $25.95 \%$ & $30.33 \%$ \\
\hline \multicolumn{7}{c}{ Source: Secondary data processed (2019) }
\end{tabular}


Therefore, humans here are only as His representatives (khalitullah fil ardh) who have compliant consequences for all of God's laws.

Stakeholder theory explains the responsibility of company in carrying out its activities not only oriented to the company but also its usefulness to all stakeholders. According to Farag, et al. (2014), objectively sharia places justice and people's welfare as sharia objectives, besides that sharia banking with good performance is also expected to have good social behavior so that it can benefit all stakeholders, including communities in society.

Corporate responsibility to all stakeholders can be interpreted as an effort to achieve prosperity, which is the third goal of maqashid sharia. Based on this understanding, then corporate responsibility is not only measured in economic indicators, but also social factors, both corporate internal and external.

Sharia Supervisory Board or SSB is a term used in Indonesia to refer to internal supervision institutions in sharia banking (Indrawaty \& Wardayati, 2016). SSB education level is a measurement by using the level of education possessed by SSB members as a basis for measuring SSB variable. SET theory explains that God as the main source of mandate has mandated humans to behave according to His law, so the higher the SSB education, the SSB will increasingly understand about the law regarding halal and haram. This will have implications for the SSB's cautious attitude in establishing policies and products in sharia banking.

Stakeholder theory explains that corporate responsibility is not only for the company, but also for all stakeholders. This responsibility is realized by maximizing the role of each organ in the company. With a high level of SSB education, it will maximize the role of SSB in conducting supervision in sharia banking. The higher the level of SSB education, the better the performance will be in carrying out the mandate given by stakeholders. Research by Asrori (2014), Maria \& Agustina (2018) and Mukhibad (2019) show that SSB has a significant positive effect on the performance of maqashid sharia.

\section{$\mathrm{H}_{1}$ : Sharia Supervisory Board has a significant positive effect on the performance of maqashid sharia}

Proportion of board of independent commissioners is a proportion that shows the number of independent commissioners to the number of commissioners in Islamic banking. The SET theory explains that the main responsibility of humans is to God. An independent commissioner is a commissioner who plays a role by working independently and not being intervened by any party, so that the ultimate accountability is only to God. This causes the more the proportion of independent commissioners, the more parties will work independently so as to encourage the achievement of companies maqashid sharia.

Stakeholder theory explains that corporate accountability is to all stakeholders. With the role of an independent commissioner as an independent party, the possibility of misusing stakeholders' trust will be even smaller. This makes the greater the proportion of independent commissioners, then the better the performance of management in prioritizing the interests of stakeholders, so that the maqashid sharia will be achieved. Research by Salsabilla \& Bachtiar (2017), Amyulianthy (2012), and Maria \& Agustina (2018) state that the greater the proportion of board of independent commissioners, the better the achievement of maqashid sharia.

\section{$\mathrm{H}_{2}$ : Proportion of Board of Independent Commis- sioners has a significant positive effect on the performance of maqashid sharia}

Board of directors 'meeting is the number of board of directors' meetings for one year. SET theory explains that God is as the main source of mandate, so that every human activity is always maximized as a form of accountability to God. This has implications as more and more boards of directors hold meetings with a discussion agenda on strategies for achieving maqashid sharia, it can be interpreted that directors have carried out their responsibilities towards God well.

Stakeholder theory explains that the responsibility carried by the company is to all stakeholders who have given trust. By holding a meeting of the board of directors with a discussion agenda in accordance with their duties, it means that the directors have done their responsibilities well. The more directors hold meetings, the more discussion will be related to the company's strategy to achieve the welfare of all stakeholders so as to achieve maqashid sharia. This result is supported by Windah \& Andono (2013),Hartono \& Nugrahanti (2014), and Orazalin \& Lee (2016).

\section{$\mathrm{H}_{3}$ : Board of Directors' Meeting has a significant positive effect on the performance of Maqashid sharia}

\section{RESEARCH METHODS}

This research was a quantitative study conducted on Islamic banking registered as Sharia Commercial Bank (BUS) in FSA in 2013-2018. The total population of 11 BUS was chosen using purposive sampling and 9 BUS companies were obtained with sample selection criteria in table 2 . The total observations consisted of six years to obtain 66 units of analysis. Of this amount, it was subtracted from the data that did not fit the criteria as many as 12 data so it produces 54 units of analysis, which can be seen in table 2 .

The dependent variable in this study was the performance of maqashid sharia. The independent variables in this study were SSB which was measured using SSB education level, proportion of independent commissioners, and board of directors meetings. The variables of SSB and board of directors' meeting used ordinal scale, proportion of board of independent commissioners used a ratio scale, while maqashid sharia performance variable used an index ration obtained from the weighting of Sample Additive Weighting (SAW). The operational definitions of each variable are explained in table 3 . 
Table 2. Research Sample

\begin{tabular}{lcc}
\hline \multicolumn{1}{c}{ Criteria } & $\begin{array}{c}\text { Beyond } \\
\text { Criteria }\end{array}$ & $\begin{array}{c}\text { Included } \\
\text { Criteria }\end{array}$ \\
\hline $\begin{array}{l}\text { Sharia Banking which has been in the form of Sharia Commercial Banks (BUS) in 2013 } \\
\text { Sharia Commercial Bank (BUS) published annual report and Good Corporate Governance } \\
\text { Report (GCG Report) which have been audited by independent auditors and published dur- } \\
\text { ing 2013-2018 }\end{array}$ & (2) & 9 \\
$\begin{array}{l}\text { Sharia Commercial Banks (BUS) in 2013-2018 had good and complete data in accordance } \\
\text { with the required variables }\end{array}$ & $(0)$ & 9 \\
Total observation years & & 6 \\
Companies that became research samples & 9 \\
Total analysis units (6 years x 9 companies) & \\
\hline
\end{tabular}

Source: Secondary data processed (2019)

Table 3. Operational Definition of Variables

\begin{tabular}{|c|c|c|}
\hline Variables & Definition & Measurement \\
\hline Maqashid sharia (MSI) & $\begin{array}{l}\text { The ultimate goal of sharia which leads to the } \\
\text { values of well-being and benefits and eliminat- } \\
\text { ing suffering (Mohammed \& Razak, 2008) }\end{array}$ & $\begin{array}{l}\text { nid Sharia Index (MSI) } \\
\text { nmed \& Taib, 2009) }\end{array}$ \\
\hline $\begin{array}{l}\text { Shari } \\
\text { Boarc }\end{array}$ & $\begin{array}{l}\text { The board who is responsible for giving advice } \\
\text { and suggestions to the Directors and oversee- } \\
\text { ing Bank's activities in accordance with sharia } \\
\text { principles (Bank Indonesia, 2009) }\end{array}$ & $\begin{array}{l}\text { The measurement uses SSB education } \\
\text { level } \\
\text { Doctors are given a score of } 3 \text {, Masters } \\
\text { are given a score of } 2 \text {, and others are } \\
\text { given a score of } 1 \text { (Mukhibad,2018) }\end{array}$ \\
\hline $\begin{array}{l}\text { Proportion of Board of } \\
\text { Independent Commis- } \\
\text { sioners (KOMIDN) }\end{array}$ & $\begin{array}{l}\text { of independent commissioners of a } \\
\text { f Commissioners in a company (Bank } \\
\text { ia, 2009) }\end{array}$ & $\begin{array}{l}\text { (Total Independent } \\
\text { (Total Commission } \\
\text { (Maria \& Agustina, }\end{array}$ \\
\hline $\begin{array}{l}\text { Board of Directors } \\
\text { Meeting (RAPDIR) }\end{array}$ & $\begin{array}{l}\text { Number of Board of Directors meetings (Bank } \\
\text { Indonesia, 2009) }\end{array}$ & $\begin{array}{l}\text { Number of Board of Directors meet- } \\
\text { ings in one year (Priatna, 2018) }\end{array}$ \\
\hline
\end{tabular}

Data collection method in this research was documentation. The data used in this study were taken from financial reports (annual report) and Good Corporate Governance (GCG) reports of Sharia Commercial Banks published and obtained from the official websites of each bank, while the type of data used was panel data.

Hypothesis testing in this study was conducted with descriptive technique and inferential analysis technique. The classical assumption test was done first before testing the hypothesis. This study used panel data regression analysis with data processing program Eviews 9. Panel data regression equation of interaction test using equation 1 :

$$
\text { MSI }=\alpha+\beta 1 \text { DPS }+\beta 2 \text { KOMIDN }+\beta 3 \text { RAPDIR }+e(1)
$$

The first, second, and third hypotheses will be accepted if the panel data regression coefficient shows positive and significant numbers, because the higher the level of SSB education, proportion of independent commissioners, and board of directors meetings, the better the performance of maqashid sharia. Hypotheses will be accepted if the significance value indicates a value of less than 0.05 .

\section{RESULTS AND DISCUSSIONS}

Descriptive statistical analysis used in this study includes the average (mean), standard deviation, maximum and minimum values. The numbers listed in table 4 describe information on descriptive statistics on the variables of maqashid sharia performance, SSB, proportion of board of independent commissioners, board of directors meetings. The results of the descriptive statistical analysis of each variable are explained in table 4.

The classical assumption test is carried out before

Table 4. Descriptive Statistics Test Results

\begin{tabular}{ccccc}
\hline & $\begin{array}{c}\text { Maqashid } \\
\text { Sharia Index }\end{array}$ & $\begin{array}{c}\text { Sharia Super- } \\
\text { visory Board }\end{array}$ & $\begin{array}{c}\text { Proportion of Board of In- } \\
\text { dependent Commissioners }\end{array}$ & $\begin{array}{c}\text { Number of Di- } \\
\text { rectors' Meetings }\end{array}$ \\
\hline Mean & 34.14 & 2.69 & 0.70 & 36.35 \\
Maximum & 49.21 & 3.00 & 1.00 & 108.00 \\
Minimum & 21.40 & 2.50 & 0.50 & 12.00 \\
Std. Dev. & 6.58 & 0.23 & 0.17 & 17.15 \\
Observations & 54 & 54 & 54 & 54 \\
\hline \multicolumn{5}{r}{ Source: Secondary data processed (2019) }
\end{tabular}


testing the hypothesis with panel data regression analysis. Based on Basuki \& Prawoto (2016), in panel data regression not all classical assumption tests that exist in the OLS method are performed, only multicollinearity and heteroscedasticity are needed. The heteroscedasticity test using Harvey test concludes there is no heteroscedasticity problem because the value of $\mathrm{Obs}^{*} \mathrm{R}$-squared of 0.57 with probability $\mathrm{X}^{2}>0.05$. The multicollinearity test shows the result that there is no multicollinearity because the level of correlation between independent variables does not exceed 0.8 .

The model test is done to choose the best model between Common Effect Model (CEM), Fixed Effect Model (FEM), and Random Effect Model (REM). In this study, the REM model is chosen as the best model as a panel data regression model. The results of the coefficient of determination show adjusted $\mathrm{R}^{2}$ value of 0.03 . This shows that the $3 \%$ variant of maqashid sharia performance variable that is proxied by Maqashid Sharia Index (MSI) can be explained by the variance of SSB, proportion of board of independent commissioners, and board of directors' meetings variables. Regression equation in this study can be written in equation Formula 2. The results of hypothesis testing in this study are presented in Table 5.

\section{MSI $=24.65+4.56 \mathrm{DPS}-3.17 \mathrm{KOMIDN}-1.01$ RAPDIR}

\section{The Effect of Sharia Supervisory Board on the Per- formance of Maqashid Sharia}

The result of this study indicates that the SSB education level has no effect on the performance of maqashid sharia. This finding has not been able to support The Sharia Enterprise Theory (SET) and stakeholder theory. The SET theory explains that the higher the SSB education will have implications for prudent behavior and adhere to sharia principles in establishing policies and products in sharia banking so as to achieve sharia objectives (maqashid sharia). Stakeholder theory explains that a company that has SSB with a high level of education will have an increasingly better ability to perform its performance, so that it can achieve maqashid sharia which one of the points is to achieve maslahah or the welfare of all parties (stakeholders).

According to Mukhibad (2019), SSB education level is not significant to maqashid sharia performance as SSB only plays a role in ensuring Sharia banking compliance with DSN MUI fatwa. SSB has no role in improving Sharia banking performance, in this case maqashid sharia performance.
According to the profile of the Shariah Supervisory Board in the Good Corporate Governance Report of the sample banking shows that the level of SSB education in the form of doctor, magister or other is not offset by the appropriate educational background, namely Sharia banking. This makes the knowledge that SSB has less comprehensive.

Farook, et al. (2011) mention that SSB with a doctorate in business and economics would play a better role in Islamic financial institutions. Based on this, a well-educated SSB with the right background will influence to the maqashid sharia.

Banking which has SSB with a higher education level or not, has the same potential for producing maqashid sharia performance, if that is not offset by SSB education background and maximization of SSB main tasks and functions in the achievement of maqashid sharia performance. This finding supports the research conducted by Kholid \& Bachtiar (2015), Priatna (2018), and Mukhibad (2019) stating that SSB has no effect on the performance of maqashid sharia.

\section{The Effect of Proportion of Board of Independent Commissioners on Maqashid Sharia Performance}

The research result shows that the proportion of board of independent commissioners does not affect on the performance of maqashid sharia. Big or small proportion of board of independent commissioners does not guarantee the achievement of maqashid sharia performance. Hartono \& Nugrahanti (2014) explained that it is possible for the existence of independent commissioners in the sharia banking structure not to uphold GCG but only to comply with regulation under PBI regulation number 11/3 / PBI / 2009 which requires the number of independent commissioners to be $50 \%$ of the number of commissioners. This led to the existence of board of independent commissioners for formalities only.

Another reason is that under PBI regulation No. 11/3 / PBI / 2009, independent commissioners are appointed and dismissed in the AGM, so the majority shareholder vote in the AGM is very influential. This makes the performance of the board of independent commissioners must be in accordance to the rules of majority shareholders. Accordingly, then the board of independent commissioners in carrying out their duties cannot be completely independent as limited by the majority shareholder rules.

According to Mukhibad (2019), the proportion of the independent commissioners board has no effect because the maqashid sharia has not been a prior-

Table 5. Hypothesis Test Results

\begin{tabular}{clccc}
\hline No. & \multicolumn{1}{c}{ Hypothesis } & B & Sig. & Decisions \\
\hline 1. & SSB has a significant positive effect on MSI performance & 4.56 & 0.06 & $\mathrm{H}_{1}$ rejected \\
2. & $\begin{array}{l}\text { Proportion of board of independent commissioners has a significant positive } \\
\text { effect on MSI performance }\end{array}$ & -3.17 & 0.25 & $\mathrm{H}_{2}$ rejected \\
3. & $\begin{array}{l}\text { Board of directors meetings have a significant positive effect on MSI } \\
\text { performance }\end{array}$ & 0.52 & $\mathrm{H}_{3}$ rejected \\
\hline
\end{tabular}


ity for banking achievements. The maqashid sharia just reached the stage concept but has not yet been implemented through regulations issued by Bank Indonesia. The structure of sharia banking GCGs is still focused on conventional performance. This is proven by research of Salsabilla \& Bachtiar (2017) stating that the proportion of independent commissioners has a significant positive effect on the performance of the company as measured by its efficiency.

This finding has not been able to support SET theory and stakeholder theory. SET theory explains that an independent commissioner is a board of commissioners who is not intervened by anyone and focuses on the achievement of the maqashid sharia. Stakeholder theory explains that as the proportion of independent commissioners increases, it is hoped that the management will do its duties well by achieving maqashid sharia. This is consistent with the results of the study by Hartono \& Nugrahanti (2014), Maria \& Agustina (2018), and Mukhibad, (2019) proving that the proportion of independent commissioners does not affect the performance of the maqashid sharia.

\section{The Effect of Board of Directors' Meeting on Maqa- shid Sharia Performance}

The result of this study indicates that the board of directors' meeting does not affect on the performance of maqashid sharia. The small or big number of meetings conducted by the board of directors does not affect the performance of maqashid sharia. The results of this study are in line with the research result of Priatna (2018), which states that the number of board of directors' meetings does not affect the performance of maqashid sharia.

The number of board of directors' meetings has no effect on the performance of maqashid sharia it is possible due to the ineffectiveness of meetings conducted by the board of directors in sharia banking which lead to the ineffectiveness of the board of directors in carrying out their duties to achieve the objectives of sharia maqashid. Based on the minutes of the board of directors meeting attached to the sample Good Corporate Governance Report, it appears that the agenda of discussion in the board of directors' meeting is still focused on achieving financial performance, while the discussion on strategies for achieving maqashid sharia has not been optimized.

This ineffectiveness can also be seen from the average attendance of the board of directors which is also attached to the sample Good Corporate Governance Report, of which only 4 out of 5 board of directors are present at each meeting. This causes the thinking contribution of board of directors is not maximal in achieving sharia goals. In addition, the insufficient number of directors attending the meeting can hamper coordination and it is feared that this will result in miscommunication between boards of directors in carrying out their responsibilities. Thus, the board of directors' meeting does not really affect the performance of maqashid sharia.

This finding has not been able to support the
SET theory and stakeholder theory. The SET theory explains that the board of directors is responsible to God by maximizing the number of meetings discussing the strategies of maqashid sharia achievement. Stakeholder theory explains that the more number of board of directors meetings, the more maximum the discussion will be related to the company's strategy to achieve the welfare of stakeholders. The result of this study is in line with research conducted by Al-Matari et al. (2012) and Priatna (2018) which state that the board of directors has no effect on the performance of maqashid sharia.

\section{CONCLUSIONS}

The results of the study conclude that the SSB measured using SSB education level, proportion of board of independent commissioners and board of directors meetings do not affect the performance of maqashid sharia. High or low SSB education level, large or small proportion of board of independent commissioners, and many or less the board of directors' meeting do not have an effect on the performance of maqashid sharia as long as maqashid sharia has not been made as a priority in the achievements of sharia banking. The limitation in this study is that the study is conducted with sharia banking objects from 2013 so that the number of BUS is still limited and has not increased. In its development, the number of BUS has increased to 14 in 2018.

Further studies are suggested to increase research years, expand research population, and add more comprehensive Islamic Corporate Governance variables, namely SSB education background and the percentage of directors meeting attendance. The addition of these variables is intended to prove the role of the sharia supervisory board and the board of directors that influence maqashid sharia through other measurements as has been described in this study. Suggestion for companies is the implementation of maqashid sharia as an indicator of sharia banking performance so that it is not only profit oriented but also welfare oriented. Suggestions for policymakers to make policies to apply maqashid sharia as an indicator of company performance so that the objectives of sharia banking are different from conventional banking and in accordance with sharia objectives.

\section{REFERENCES}

Adams, R. B., \& Mehran, H. (2012). Bank Board Structure and Performance: Evidence for Large Bank Holding Companies. Journal of Financial Intermediation (Elsevier), 21(2), 243-267. https://doi.org/10.1016/j. jfi.2011.09.002

Al-Matari, Y. A., Al-Swidi, A. K., Fadzil, F. H. B., \& Al-Matari, E. M. (2012). Board of Directors , Audit Committee Characteristics and Performance of Saudi Arabia Listed Companies. International Review of Management and Marketing, 2(4), 241-251.

Amyulianthy, R. (2012). Pengaruh Struktur Corporate Governance Terhadap Kinerja Perusahaan Publik Indonesia. Jurnal Liquidity, 1(2), 91-98.

Antonio, M. S., Sanrego, Y. D., \& Taufiq, M. (2012). An Analysis of Islamic Banking Performance: Maqashid Index Implementation in Indonesia and Jordania. 1(1), 12-29. 
Asrori. (2014). Implementasi Islamic Corporate Governance dan Implikasinya Terhadap Kinerja Bank Syariah. Jurnal Dinamika Akuntansi, 6(1), 90-102. Retrieved from http://journal.unnes.ac.id/nju/index.php/da

Bank Indonesia. Pelaksanaan Good Corporate Governance bagi Bank Umum Syariah dan Unit Usaha Syariah., Pub. L. No. PBI Nomor 11/33/2009 (2009).

Basuki, A. T., \& Prawoto, N. (2016). Analisis Regresi dalam Penelitian Ekonomi \& Bisnis (Dilengkapi dengan Aplikasi SPSS \& Eviews) (1st ed.). Jakarta: PT RajaGrafindo Persada.

Bhatti, M., \& Bhatti, M. I. (2010). Toward Understanding Islamic Corporate Governance Issues in Islamic Finance. Asian Politics \& Policy, 2(1), 25-38.

Farag, H., Mallin, C., \& Ow-yong, K. (2014). Corporate Social Responsibility and Financial Performance in Islamic Banks. Journal of Economic Behavior and Organization, 103(supplement). https://doi.org/10.1016/j. jebo.2014.03.001

Farook, S., Hassan, M. K., \& Lanis, R. (2011). Determinants of Corporate Social Responsibility Disclosure: The Case of Islamic Banks. Emerald Insight, 2(2), 114-141. https://doi.org/10.1108/17590811111170539

Hartono, D. F., \& Nugrahanti, Y. W. (2014). Pengaruh Mekanisme Corporate Governance Terhadap Kinerja Keuangan Perusahaan Perbankan. 3(2), 191-205.

Holili, T. (2017). Analisis Penerapan Good Corporate Governance Bisnis Syariah dan Pencapaian Kinerja Perbankan Syariah Indonesia Ditinjau dari Maqashid Syariah dan Profitabilitas. Jurnal Akuntansi FEB Universitas Mataram, 1(1), 1-13.

Indrawaty, \& Wardayati, S. M. (2016). Implementing Islamic Corporate Governance (ICG) and Islamic Social Reporting (ISR) in Islamic Financial Institution (IFI). Procedia (Social and Behavioral Sciences), 219(2), 338-343. https://doi.org/10.1016/j.sbspro.2016.04.042

Kholid, M. N., \& Bachtiar, A. (2014). Pengaruh Dana Syirkah Temporer dan Good Corporate Governance terhadap Kinerja Maqasid Syariah Bank Syariah di Indonesia. E-Jurnal Manajemen Unud, 7(3), 1-25.

Kholid, M. N., \& Bachtiar, A. (2015). Good Corporate Governance dan Kinerja Maqasid Syariah Bank Syariah di Indonesia. JAAI, 19(2), 126-136.

Maria, D., \& Agustina, F. (2018). Improvement of Maqoshid Shariah Performance. IJSSD: International Journal Of Social Sciences And Development, 2(1), 78-87.

Meutia, I. (2010). The Concept Of Social Responsibility Disclosure For Islamic Banks Based On Syari'ah Enterprise Theory. Jurnal Akuntansi Multiparadigma, 1(3), 361-374.

Mohammed, M. O., \& Razak, D. A. (2008). The Performance Measures of Islamic Banking Based on the Maqasid Framework. Malaysia.

Mohammed, M. O., \& Taib, F. (2009). Testing the Performance
Measures Based on Maqashid al-Shari'ah (PMMS) 24 Model Selected Islamic and Conventional Banks. In 2nd Langkawi INSANIAH-IRTI International Conference (LIFE) (pp. 1-15).

Mukhibad, H. (2018). Peran Dewan Pengawas Syariah dalam Pengungkapan Islamic Sosial Reporting. Jurnal Akuntansi Multiparadigma, 9(2), 299-311. https://doi.org/ http://dx.doi.org/10.18202/jamal.2018.04.9018

Mukhibad, H. (2019). The Role Of Sharia Supervisory Boards in Meeting Maqasid Syariah - Study on Islamic Banks in Indonesia. EJIF- Europan Journal of Islamic Finance, (13), 1-10.

Orazalin, N., \& Lee, M. M. K. J. (2016). Corporate Governance : The International Journal of Business in Society Article Information: Corporate Governance, Financial Crises and Bank Performance : Lessons from Top Russian Banks. Emerald Insight, 16(5), 798-814. https://doi.org/10.1108/CG-10-2015-0145.

Orazalin, N., \& Mahmood, M. (2018). The Financial Crisis as A Wake-Up Call: Corporate Governance and Bank Performance in An Emerging Economy. Emerald Insight, 19(2), 80-101. https://doi.org/10.1108/CG-022018-0080

Prasinta, D. (2012). Pengaruh Good Corporate Governance. Accounting Analysis Journal, 1(2), 1-7.

Priatna, A. (2018). Dana Syirkah Temporer dan Corporate Governance Mechanism Terhadap Kinerja Maqasid Syariah Bank Syariah. AL-URBAN: Jurnal Ekonomi Syariah Dan Filantropi Islam, 2(2), 116-124. https:// doi.org/10.22236/alurban_vol2/ispp116-124

Rahman, F. K., Tareq, M. A., Yunanda, R. A., \& Mahdzir, A. (2017). Maqashid Shari'ah-Based Performance Measurement for Halal Industry. Emerald Insight, 13(3), 357-370. https://doi.org/10.1108/H-03-2017-0054.

Rusydiana, A. S., \& Sanrego, Y. D. (2018). Measuring The Performance of Islamic Banking in Indonesia: An Aplication of Maslahah-Efficiency Quadrant (MEQ). Journal of Islamic Monetary Economics and Finance, 3, 79-98.

Salsabilla, S., \& Bachtiar, A. (2017). Pengaruh Good Corporate Governance terhadap Kinerja Cost Efficiency Asuransi Syariah dan Unit Usaha Syariah. EFEKTF Jurnal Bisnis Dan Ekonomi, 8(1), 39-54.

Sudrajat, A., \& Sodiq, A. (2016). Analisis Penilaian Kinerja Bank Syariah Berdasarkan Indeks Maqasid Shari'ah (Studi Kasus pada 9 Bank Umum Syariah di Indonesia Tahun 2015). BISNIS, 4(1), 178-200.

Windah, G. C., \& Andono, F. A. (2013). Pengaruh Penerapan Corporate Governance Terhadap Kinerja Keuangan Perusahaan Hasil Survei The Indonesian Institute Persception Governance (IICG) Periode 2008-2011. Calyptra: Jurnal Ilmiah Mahasiswa Universitas Surabaya, 2(1), 1-20. 